\title{
Pathways of ANALYSis ON COSTUME IN PORTUGUESE ETHNOFICTION FILMS
}

\author{
Caterina Cucinotta
}

\begin{abstract}
This article explores the theme of documentary and fiction in the ethnofiction Portuguese cinema, with the costumes in the middle of this binomial as a phenomenon that explains it as a likelihood of the sequences and as a tool to create a simulation of the reality. We treat the term ethnofiction as it would be a cinematographic genre and we choose, as an example to analyse, three Trilogies from the Portuguese cinema. Also we treat the costumes according to the new concept about the clothed body that come from Fashion Theory. To analyse films costumes by the genre helps to create of a first definition of this kind of clothing and to understand its importance inside a filmic action. The theoretical parts about Fashion Theory and about the ethnofiction concept will be applied to the chosen films, trying to extend the knowledge through the introduction of others authors who also work about the two themes, to unify them, the clothed body and the ethnofiction, in the one of cinematographic costumes.
\end{abstract}

\section{Keywords}

Ethnofiction; film costumes; portuguese cinema

\begin{abstract}
Resumo
O presente artigo versa sobre o tema do documentário e da ficção no cinema de etnoficção português, focalizando-se no estudo do vestuário como fenómeno, ora votado a explicitar a verosimilhança das sequências, ora usado enquanto ferramenta para criar uma simulação da realidade. Tratamos o termo etnoficção como se fosse um género cinematográfico e escolhemos, como exemplo de análise três trilogias do cinema português. Entendemos o vestuário de acordo com os novos conceitos do corpo revestido que vêm da Fashion Theory. Analisar o vestuário de filmes por género ajuda, por um lado, na criação de uma primeira definição de todo este tipo de vestuário e, por outro, a compreender a sua importância dentro de uma obra fílmica. O enquadramento teórico sobre Fashion Theory e sobre o conceito de etnoficção será aplicado aos filmes escolhidos, tentando-se ampliar os referidos conhecimentos através da introdução de outros autores que se debruçaram sobre os dois assuntos, a fim de unificar os dois conceitos, do corpo revestido e da etnoficção, num só, o conceito de vestuário cinematográfico.
\end{abstract}

\section{Palavras-chave}

Cinema português; etnoficção; vestuário cinematográfico 


\section{INTRODUCTION}

In this essay we introduce an analysis on clothing design in the sense of "costume design", in Portuguese films dividing them in Trilogies focusing our attention on the crossover between cinema and fashion from a comparative point of view.

This study' can be defined as a preliminary outline for a discourse on cinematographic costume, where the specific objective is to apply the Fashion Theory to a cinematographic genre. In choosing this path, we intend to express the strategy of a methodology that implements similar discourses which may be useful as a starting point for other researchers of the image in motion who are also interested in the body, its garments and the implications of these within the framing in the plane of a film.

The Fashion Theory, more than a simples study on fashion, requires the understanding of the moods and of the gestures fixed in the costumes. These are not mentioned statements that, in covering the body, they extend, duplicate or suspend the gestures of the characters. It will be developer when we talk about ethnofiction, a cinematographic genre that mixes documentary and fiction.

The Fashion Theory will serve as a theoretical groundwork and starting point to undertake an analysis methodology that crosses clothing with Film Studies and we have chosen ethnofiction as the object of study, highlighting some Portuguese films constituted in trilogies.

The first trilogy will be Leitão de Barros's Trilogy of the Sea: Nazaré, Praia de Pescadores e Porto de Turismo (1927), Maria do Mar (1929) e Ala arriba! (1942).

The second one is António Reis and Margarida Cordeiro's Trilogy of Trás-os-Montes: Trás-os-Montes (1976), Ana (1982) and Rosa de Areia (1989).

The third and final one is Pedro Costa's Trilogy of Fontainhas: Ossos (1997), No Quarto de Vanda (2000) and Juventude em Marcha (2006).

\section{Formulation OF THE PROBLEM}

At the beginning of the third chapter of Changing Places: Costume and Identity by the British researcher Pam Cook, the author writes:

clothing design is one of the least researched areas in film history. There is a wide range of literature on theatrical costume, and since the 1970 there has been a growing interest in fashion in the circle of Culture historians. However, most part of them did not follow the Film Studies trend. (...) the lack of interest in costume design becomes particularly significant if we consider how important it is for the narrative, the creation of characters, the strengthening of the plot, the suggestion of environments, etc. (Cook, 1996, p. 41)

This text was originally published in 1996, and until now there have been very few changes on the subject. However, if anything changed in the current days, it is only

\footnotetext{
' This article is the result of a re-elaboration of the Phd research with the title $O$ vestuário no cinema: percursos de analise em
} filmes portugueses de etnoficção. For further information: https://run.unl.pt/handle/10362/16297 
because costume design has probably begun to be regarded as an important element in the understanding of a film work. Yet, according to Cook, after all these years the genesis of this investigation remains unchanged.

In addition to its general function in the visual understanding of images on motion, clothing design helps in the construction of paths parallel to the central storyline. It provides information about characters and the historical and social context in which they act. It is a means of communicating likeliness and it is able to establish a sort of pact between the film and the viewer who is thus led to believe that what he sees on the screen is "true". Therefore, one of the first problems is that cinematographic clothing has never enjoyed a detailed and parallel analysis within film studies.

In accordance with the research carried out, the first studies on theatrical costumes accessible online and in specialized libraries date back to the first half of the last century and represent a discreet origin in the path to carry out in the filmic universe of clothing. In France and Italy, from the 1940s onwards, many costumers wrote brief treatises or essays on their own work (Annenkov, 1955, Sensani \& Lara quoted in Verdone, 1986), and the same thing had already happened with Hollywood costume designers (Adrian, quoted in Watts, 1939, Banton, 1935). In spite of this, one had to wait until 1950 the year Mario Verdone, professor of Filmology in Rome, edited the book Scena and Costume nel Cinema ${ }^{2}$, for a careful and detailed work that departed somewhat from the perspective of fashion, in order to introduce costume design into the real world of cinema. The text deepens some historical as well as cultural aspects of scenography and filmic costume design, starting with cinema and not fashion in the case of clothing, and cinema, not architecture, in the case of scenography. This seems to be a more complete work than the previous ones, because it tries to put aside mere curiosities "from the fabulous world of cinema, made of glamour and divas, to concentrate on drawing up a research outline of the filmic element in clothing itself".

The point is not to dress people with what fits them better, but to dress the images, to create a character, to participate in the elaboration of a 'ghost'. Thus, needs arise that have almost nothing to do - at least directly - with fashion, with the great fashion designers, the Parisian mania, the history of art, folklore and crafts. (Verdone, 1986, p. 40)

The concept of dressing the images, proposed by Verdone, is of particular interest and, peculiarly, has a close connection with the innovative concept of Surface materiality in film by Giuliana Bruno (2014).

The biggest obstacle in this type of investigation is the little importance that the film studies gave to costume design as a dramatic element in the communication of a film. Cinematographic clothing has not gained a dominant position in academic studies because it has always been mistakenly understood as a purely decorative element. The crossroads between cultural studies and semiotic studies state exactly the opposite:

\footnotetext{
${ }^{2}$ Text consulted in its edition of 1986.
} 
clothing within a film, whatever the genre, always conveys some sense, some feeling, related to the film and the director who thought it (Bruno, 2014). Moreover, while on the one hand the clothing of a fiction film is the result of careful reconstructions based on cultural stereotypes, on the other, the clothing of an ethnofiction exposes peculiar and unusual aspects.

In general, the guiding thread of this investigation centers on the use that the cinema makes of clothing as a vehicle for tracing axes parallel to the main narrative. That is, the minor importance given to clothing design by film studies, so far, becomes the starting point of this study. Therefore, it is proposed, as the main problematic, an attempt to apply a theory to a cinematographic genre arisen in the studies on fashion and costume, which has the name of Fashion Theory.

\section{ThE FASHION THEORY AS THE BASIC THEORY}

The term Fashion Theory refers to an interdisciplinary scope that contemplates fashion as a system of meanings in which the cultural and aesthetic representations of the clothed body are produced. According to our study tour, I analysed fashion as a "constructer of meanings" and figures of the imaginary, or myths, which reproduce themselves in the social sphere, making them natural and eternal. The media, first and foremost the cinema, are a great deposit and engine of the social imaginary and act in close synergy with fashion.

Several are the axes that define / integrate Fashion Theory. Namely, with regard to costume or clothing: anthropology, sociology, philosophy, psychology, semiotics and cultural studies. From an article by Patrizia Calefato (2002) entitled Fashion Theory, an effort was made to organise chronologically the fundamental points of the time when the theory began to emerge, until it developed itself in the current concept. From Georg Simmel's 1895 essay on fashion (Simmel, 1996) to the writings of Roland Barthes, I will make an attempt to illustrate the theories that put fashion and costume at the centre of the investigation trying not to fall into purely textual or Historical analyses.

In his own way, Simmel was a predecessor for he inserted fashion within the individual / society binomial and from this binomial others were born: male/female, rich/ poor or imitation/ differentiation. Binomials with which, first Simmel and later, in 1897, Veblen (1969) started deducing how much fashion, before being understood in general terms, needed to be framed in society in order to better understand its function. Following the chronological course indicated by Calefato (2002), it becomes necessary to methodically examine Structuralism to better understand the distinction between fashion and costume. It was Saussure in 1967 (2009) who brought fashion to language, and from then on, other semiotics and historians of culture became interested in clothing design. In 1937, Petr Bogatyrëv (1937/1986) published an essay on folkloric costumes where he applied the functionalist method to clothing, individualizing within it a grade of five main functions.

In Bogatyrëv's case, what makes his analysis interesting is the construction 
according to a functionalist system, which individualizes the folkloric costume in a hierarchy of functions. During the study, in contrasting fashion and costume the author finds strong disparities between the two phenomena: while the former acquires a sense only in function of change and rupture with the past, the latter lives on in continuity and tradition. Bogatyrëv's attention (1937/1986, pp. 93-94) is drawn by the stability and predictability of the popular costume, and in 1937 he will reach its definition trough five functions of the costume: aesthetic, erotic, practical, magical and regional.

Having in mind Roland Barthes's thinking (2009/1957-1963), he refined the knowledge about fashion as a social discourse by introducing the concept of "clothed body", and from these other concepts derived such as "body show" or "young body" leading, finally, to the contemporary concept developed in the work of another linguist, Patrizia Calefato. Since the late 1980s, the Italian researcher and teacher has been developing the theory of the clothed body linked to the studies on Fashion Theory, within the so-called mass-fashion and body performance:

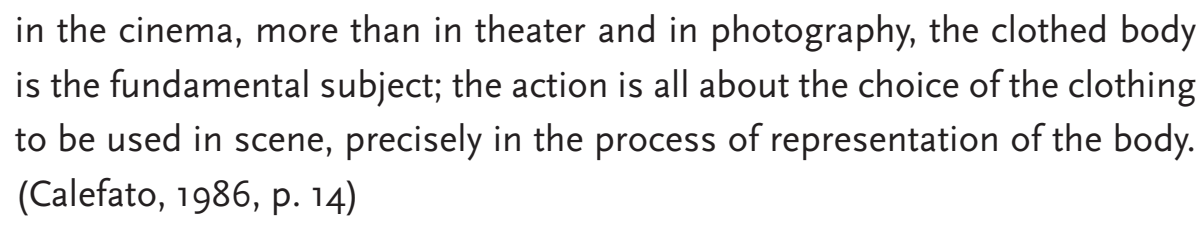

It is a different discourse about the body trying to exclude the extremes, meaning "pronouncing the body" through its masks. One may try to "pronounce the body" in its infinite openings with other bodies and with the world giving it "a strength related to the culture within which these images are set" (Calefato, 1986, p. 8). In the mid-1970s, certain feminist investigations focused their attention on the cinematographic construction of the female body as an object wholly trapped within a patriarchal vision of human relations and power. In this regard, Laura Mulvey, in a 1974 essay (translated into Italian in 1978) separates the man from the woman into the cinematographic device. She defined the first as the eye that looks and the second as the spectacle to be looked at or, more specifically as "the performance" to look at. According to Patrizia Calefato, thanks to these pioneering researches it was possible to constitute a theoretical basis on which, during the 80's of the last century, an analysis of the cinematic corporeality began. This also comprehended theatrical costumes, decisive in the construction of "the masculine" and "the feminine". Therefore, the clothed body is the physical-cultural territory where the visible and sensitive performance of our outer identity is accomplished.

\section{The Portuguese ethnofiction as object of STUdy}

The Portuguese ethnofiction, a crossover between documentary and fiction, was chosen as the generator of an important intersection also in terms of clothing design. Placing the clothing exactly between the real and the fictitious, it works now as a symbol of truth in the story told, a reconstruction of the concept of community.

In gathering all the research done over the years, and in an effort to unify the three trilogies analysed in a single definition of cinematographic genre, some doubts about the 
material researched began to be clarified. Generally, it is accepted that websites such as Wikipedia.com cannot be cited as a single source and solution to questions, since the search for answers in the vast universe of the internet can give shape to other issues that, when they deviate of the central discussion, can create confusion in the search for a resolution. However, on the other hand, in relation to the specificity of the concept of ethnofiction and its definition from the cinematographic point of view, the truth is that the first answers were found on the internet. In fact, when one decides to research about a cinematographic genre that has so limited well grounded references it is thought that one of the few viable pathways is to gather as much information as possible and then combine pieces into the conceptual fragmentation that each film can put forward on the subject.

Considering that the concept of ethnofiction has its origin in the discipline of visual anthropology $y^{3}$, it should be added that only a few years ago it began to be used in the cinematographic field, having been recognized as a genre. One of the first interesting definitions offered is that ethnofiction ${ }^{4}$ is the cinematographic genre that has as object of study a group of people which constitutes a community. Starting from here, in general, in the analysis of the contents the object of study can be individualized in the man who, living in a community, accepts / adopts certain rules and leaves others. In order to possess the characteristics that define it as a work of ethnofiction, a film should focus its attention on two main axes: on the one hand, we find individual behaviours that emphasize the subjective personality and, on the other, there is an impetus on the community's behalf in order these behaviours do not destabilize the internal balance of the latter. Although the subject matter is important, the element that most contributes to turn an ethnographic film into an ethnofiction is the methodology used to deal with the filming itself, that is, in addition to the contents the forms are fundamental too. Actually, it is rather difficult to consider that a film can balance itself in a complete sintony between the forms of documentary and fiction, having in mind the use of the documentary itself as a methodology, and on the other, forcing the hand with the Fiction paradoxically used as a mirror of reality. But perhaps the most interesting part of this new conceptualization lies in the lapse in which the documentary masks itself of fiction and the fiction masks itself of documentary to pretend that it is fiction, and vice versa.

In other words, the debate about ethnofiction has generated a great deal of interest in the scope of cinematographic issues because what we define as ethnofiction others give the name of "Film-Essay" (Rascaroli, 2009) or "Indisciplinary Cinema" (Overhoff Ferreira, 2013), and it is not concerned here to assign definitions to an object that does not need to be defined. What is emerging here for debate is the questioning of how moving images create connections with other languages, other worlds, other arts; how, through these links, directors become artists on other levels as well; and how the association between arts and cinema generates concepts parallel to the plot of a film.

\footnotetext{
${ }^{3}$ Since 1992, exists in Portugal the NAV, Núcleo de Antropologia Visual. Retrieved from http://ceas.iscte.pt/gr_avisual.php ${ }_{4}^{4}$ Retrieved from http://pt.wikipedia.org/wiki/Etnoficção
} 


\section{THE THREE LEVELS OF ANALYSIS}

To achieve the goal of the creation of connections between different languages as fashion and cinema, we sought a useful methodology in order to analyze garments present in the sequences of the chosen films. Moreover, it is a methodology that can be used also in the approach of other languages, different from fashion and clothing, present in one of the films.

In addition, we are referring to the analysis according to three levels: cinematography, extra-cinematography and filmic (Calefato, 2007; Giannone, 2007).

While the first two analyse information of the different social, psychological and cultural characteristics of the individual or actor who wears a garment, the latter turned out to be most appropriate for the purpose of this investigation. The analysis of the pieces of clothing was intended to be more filmic like observing them from the point of view of the camera and not only the individual who wears them, since the theatrical costume is one of the elements that the director has to approach to the truth and/or to fiction.

Broadly speaking, the cinematographic level represents the relationship between the actual use of garments and the use of clothing designed for the two-dimensional fiction of the screen: there are pieces that work in real life but do not fit well with the rules and aesthetics of the screen in terms of colour and texture. The extra-cinematographic level is perhaps the opposite, because theatrical clothing also conveys to the viewer a re-elaboration of reality through the stereotypes and visual identities he or she creates. In a way, the cinematic images bring reproducible models to the real world much in part due to the pieces of clothing.

Finally, the filmic level is the most complex and it is where clothing design becomes important because it is part of the close connection between actor and character - what the actor wants to convey to the viewer has an exterior beginning in his/her clothing. In this sense, clothing can represent a fundamental voice in Greimas's (1985) veridiction contract, which each film stipulates with its spectator, who consciously decides to believe what fictional images show him on the basis of contract coherence. Greimas writes:

speech is a fragile place where truth and falsehood, lies and secrecy are inscribed and read; (...) a more or less stable balance that comes from an implicit agreement between the 'speaker' and the 'addressee' of the communication structure. This tacit compromise is called a fiduciary agreement. $(1985$, p. 45)

Finally, the filmic level is also important because, in most cases, it is the creator of narrative lines that are parallel and invisible to the main plot.

Considering that an essential ground in the construction of cinematographic characters is a harmonious suitability of clothing, it can be understood how this element has been undervalued. This is a key element in the reading of cinematic enjoyment because, at the unconscious level, what is simply called clothing can operate a synthesis between the character's inner characteristics and the difficult transformable physical characteristics of the actor-interpreter. The performative side of cinematographic clothing is thus 
clarified: if the spectator can believe that an actor known through other media, with an existence beyond the immediate film, can be that character in an integral part of the parallel film world that he becomes a part, then this happens thanks to his clothing too. Through this process he contributes to allow a passage from real life to fiction, making fiction credible.

It is through the contract of veridification that the rules, which provide the structure to the possible world created on the film screen, are expressed. If, on the one hand, the spectator suspends his disbelief in relation to the filmed sequences, it is also because the director, in his turn, is concerned to make clear in what kind of environment the narration unfolds, trying to combine actor, place, time and event. It is a kind of passage of official record between the director and the viewer that culminates in the choice of appropriate clothing. This also guarantees that the chosen film genre is not unintentional. In ethnofiction, in the documentary in general and in the ethnographic documentary specifically, the contract of veridification appears with a rather greater spontaneity, because it is not day-to-day clothing but folkloric costumes full of their own meanings. By adding to the costumes elements related to a place, it becomes evident the director's will: he wants the viewer to believe that what he is seeing is in fact real, true, existing.

\section{The analysis of The Trilogy of THE SEA}

In analysing Leitão de Barros's Trilogy of the Sea, one may be surprised at the amount of clothing references that appear from start to end in the three films, which include the importance of female costume whose function is to cover the shapes of the body and face, through unexpected links between the camera, the body and the narrative of the film.

One must underline the innovative way as Leitão de Barros approaches concepts in relation to the clothing of the body. Backing the documentary genre, used as a device, he conceives a series of fictions to (re) travel through those who are, in his view, the customs of the people of Nazaré, while introducing his personal mark. The camera changes position and attitude depending on whether it is in front of the community or in front of a single character.

Let us reflect a little on the importance given to the nudity of Maria do Mar when she is rescued by a boy from an enemy family; it is important to refer this gesture of union in the presence of two naked bodies, replacing the dress codes-symbols of their relatives' break-ups. At the beginning of the sequence we see two different groups of bathers, men and women, each with their own clothing identifying their diversity. Yet, at the moment the camera shows in detail a woman's breast, the rules of the community seem to fall. Social differences are erased at the precise moment the camera does not seem to display only the forbidden, but in fact to strip off Maria do Mar of her identity.

It is clear the intention to mislead or, at least, to confuse the viewer, showing the gesture as a coincidence, which turns it into a very powerful image. If it had happened casually, it might have been eliminated during the assembly. The director's intention lies in his willingness to show a woman stripped off her clothes, as well as, of her identity. 
In Ala Arriba! (1943), right at the beginning of the film, the viewer becomes aware of how important are the sweaters with social brand mark-codes in the community of Póvoa de Varzim, a community made of fishermen.

The film was shot in the 1940s when the main difference between the rich and the poor in clothing was basically the interest, or lack of it, in keeping up with the new trends. In the cities, people with money dressed according to what fashion dictated, while the humble people wore clothes to cover themselves. However, the phenomenon that occurs inside the closed community of Póvoa de Varzim acquires something that can be associated with fashion. Although folkloric costumes clothing are mentioned, the brands on the sweaters, different according to the social class, remind us how important it is even today to wear a garment that has printed marks that indicate which world one belongs to.

Allison Lurie (2007) states that, along History, "clothing has shown the social status of the wearer. Just as the older languages are full of elaborate titles and forms of invocation, for thousands of years certain fashion trends have indicated high-social class or royal prerogatives". When Bogatyrëv describes the social class function in daily garments, he states:

the tendency to distinguish the various classes through clothing is also preserved when there is some kind of 'progression levels': from rural to local clothing, then to city clothing, and finally to international. The tendency of the various classes to make their own differences stand out is the only form which, over the various periods, is filled with different contents. (Bogatyrëv, 1986, p. 98)

Considering the phenomenon itself, one can distinguish, in fact, in the folkloric costumes a certain trend or fashion that aims to create a visual separation between rich and poor. In general, recognizing an individual as a member of a group through clothing is a standard practice. But, what is interesting in the film is the provisional form as such is shown visually - through clothing. Nothing is definite, not even wearing a sweater with different social marks thanks to a marriage - an act of love that can change the social way of a person.

\section{The AnAlysis OF The Trilogy of Trás-os-Montes}

In what concerns the second trilogy, the meaning and use of costume design was extremely relevant as a means of integrating the director's specific idea he wanted to present about the community. For example, António Reis and Margarida Cordeiro in the Trilogy of Trás-os-Montes show how in fiction and documentary costume design is directly connected with imagination, memories and places.

In addition, researchers interested in António Reis and Margarida Cordeiro's work make literally (and in practice) a great effort, from the point of view of curiosity, to watch the films of the Trilogy of Trás-os-Montes. The viewer's ritual in relation to the visibility of the film is part of a mechanism that also includes clothing, itself a bearer of magical 
meanings that, together with the aura created around the films, form the so-called "aesthetics of invisibility in the cinema of Reis and Cordeiro" (Torres, 1991-1992, p. 124). Although it may seem a bizarre subject in the case of this so obscure trilogy, it is also important to analyse the objects that are enclosed in the framings, objects that may seem simple decorations, but that tell parallel stories in relation to the narration and the characters themselves.

Regarding Trás-os-Montes, something that can be called magic happens: the boy who has just dreamed of a memory that belongs to his mother, wakes up and gets out of the bed. Apparently, the bed, the house, the furniture and the dressing gown are always the same, at least the young man does not find anything strange, and undressing his nightwear he begins to wear a button-down shirt. The camera, very carefully, observes this act of undressing through a few mouvements, only to follow him from the bed to the lavatory. When the boy has just got dressed, in front of a mirror, he puts on a reddish woolen hat, fitting it well on his head.

Here is the remarkable fact: in the following sequence, when the viewer sees the boy walking on a field with a friend, he finally understands that the act of undressing the nightwear was not only what it seemed to be, but it was some kind of magical garment with which one can muddle the time. The young man stripped off his identity to go back in time having to wear another suit, another self, and the insistence with which he put the cap on his head was the first sign of this change, a kind of adjustment. The boy's nudity reflected in the mirror, at the passing of time, seems to say that "the body is the permanent contestation of the prerogative attributed to consciousness, 'of giving meaning' to each thing. 'It lives' for it is this contestation" (Levinas 1971, p. 130). The two friends, dressed as medieval pages, wander in the fields on a long walk. Finally, when they reach the village of Montesinho it is "another" Montesinho far from the time of Luis and Armando, and one of the two boys asks: "but how can two boys like us be our ancestors? (...) Perhaps our journey did not take a few hours, but many years, a few hundred years" 5 . The faces of the two friends, the bodies themselves and the event itself can be recognised in what Louis Marin (1971) calls of "plural neutrality" that is, that utopian place that occupies the distance. Moreover, it is about what is left between the mark and the nonmark, something between truth and fiction, between the possible and the impossible, where the difference does not disappear in the synthesis, nor is it subject to the universal categories of reason, but is held, immobilized and perpetuated in the form of an infinite controversy. The costume is, therefore, the official trait of its language, of its productive time, time of affirmation of the individual as subject of the world. The Latin word habitus is the cornerstone for "costume" and the latter tries to fix the evanescent identity of a body in transit between two different times, from which the irreducibility is expressed in the traits of the faces that depict the characteristics of a community. But at the same time, the habitus plays with its identifying function by defining a kind of status through details and accessories, in this case the woolen hat, when the character becomes "a type", and place it in a well defined space / time. In addition, the details speak also of

\footnotetext{
${ }^{5}$ Minute 47:36 in film Trás-os-Montes.
} 
the ephemeral, of the continuous change that the habitus itself brings to the body, or in Onorati's words (2000, pp. 107-115), its inner self as the "writing of the body" that forges and deconstructs the relation of meaning between individual and community. Therefore, the medieval period costume "speaks" of the boy and also speaks a little about itself, of its "being" as a sign.

\section{The ANALYSis OF Trilogy OF Fontainhas}

While studying the Pedro Costa's Trilogy of Fontainhas, a feeling of amalgamation or visual coherence finally arose: the visual component of the film is linked to the clothing as the guiding thread of the concepts that are explained throughout the film, a kind of parallel plot as a support for the film, but which manages to create in the viewer an awareness of the facts narrated.

The viewer almost begins to think that Vanda herself, in the film No quarto de Vanda [In Vanda's bedroom], is the clothed body; that is to say, the film is no longer talking about Vanda and the theory of the clothed body, but of Vanda as the connection link, as a clear and visible exponent of what today is a "clothed body" in the cinema and how important this question is for the success of a film.

Pedro Costa accomplished the creation of a parallel narrative line, which passes from the clothed bodies to the houses that are being demolished in the Neigbourhood of Fontainhas.

While the neighbourhood is being demolished by the Lisbon City Hall, clothing continues to survive because it wraps the bodies of the characters, in an intimate association. The characters continue to live the same way; they do not give importance to what is happening in the streets, which seems odd once the bulldozer is going to throw everything down and people will have to leave the slum and go for a social housing. In fact, the sound that complements the sequences communicates an atmosphere of change, almost an unwanted and unwelcome transformation that no one cares about and no one else has asked for. The quick, noisy and misshapen demolition of the neighbourhood accompanies the slow destruction of the inhabitants of the Fontainhas, for whom all things will continue the same. "The continuous work of demolition never ceases to be heard, as if it was the very pulsar of those sleeping bodies" (Spaziani in Cabo, 2009, p. 191).

On the contrary, the clothing is completely pervaded with an immobility that reflects the mood of each of the characters; whether it is a sweater, a jacket or a t-shirt its importance is related to the complete immutability of not wanting to modify things. According to Pierre Bourdieu (1998), society does not exist outside bodies, because social conceptions live in bodies, in the way the world is seen and in the way one acts and reacts in it. What Bourdieu calls habitus is the consistency and constancy used in the form of how bodies act, which embody a set of notions about the world. These notions derive from the experience of what is possible, or not, within a particular social condition, and they act on a subconscious level through the expression of behavioral attitudes and practices. Each individual has a specific habitus induced by a world-experience lived from the positions occupied in society: family, education and productive process. 
These are the connections that in No Quarto de Vanda [In Vanda's bedroom] trigger complicity between the body of the actor and his clothing, mainly due to the connection between the neighbourhood and its meaning, between the director and his universal idea of what cinema is. Finally, the connection between viewer and the images he watches stimulate his ethical disposition as he feels how close that reality is.

When one refers to the connection between bodies and neighbourhood, the culture behind these elements and their relative loss must be seen as evident, a kind of double uprooting. In this way, absence becomes loss: "their houses were their own bodies. Now, they are as amputees" (Costa, 2008, p. 165). The loss of culture, therefore, is materialized in random clothing that aspires nothing more than the degradation and uselessness of those bodies. This loss is also materialized in the absence of community sequences, which are exchanged for slow plans where the ritual of injecting drug by addicts who embody ghosts without past or future.

\section{Conclusions}

The individual analysis of each film brought to the practice theoretical concepts of Fashion Theory that were suitable to fit the films in the natural linkage between documentary and fiction. The proposal to do so, from the point of view of clothing, aimed at exploring new pathways, parallel to those that already existed in the argument of a film, but at the same time as important, in the construction of the character and in his/her setting.

The aforementioned concept of ethnofiction was extremely useful in bringing together common characteristics of different films: life away from the city, closed groups, community and its rules, the constant struggle between the individual will and the rules imposed by the community itself. Not forgetting that, in the case of cinematographic works, the name of ethnofiction would also be reflected in a personal style of the director himself and of sequences never clearly fit in fiction or documentary.

In spite of far from being the fundamental concepts of fashion itself depending on Fashion Theory ideas, the starting point was the issue about the costume design of a specific ethnographic film which might have interesting elements, both in fiction and documentary, but also in its own specificity of clothed body. Although the connection between costume and ethnographic film was well-established, especially in the first two trilogies where the filmed communities lived far from the city and modern Portuguese society in general, the last trilogy was more daring in terms of novelties due to the choice of the community itself (the Bairro das Fontainhas), geographically close to the capital but far from it or with almost no relation to it, either from the point of view of the director's style that, by diluting the border between fiction and documentary, imposed stylistic, political and moral issues.

Regarding Pedro Costa, he was António Reis's pupil at the School of Theater and Cinema in the early 80's and, through his own statements, it is known that it was thanks to his teacher that he realized the richness of Portuguese old-school cinema. António Reis was a connoisseur of Portuguese historical cinema, which up to that time was only a 
"group of comedies from the 1940s" (Costa quoted in Moutinho \& Lobo, 1997, p. 62), and "from the moment I saw Trás-os-Montes, finally, I had the opportunity to start having a past in Portuguese cinema" (Costa quoted in Moutinho \& Lobo, 1997, p. 65). The connection between the films of the duo and Pedro Costa's cinema can be summarized in what he calls the "connection between plans" (Costa quoted in Moutinho \& Lobo, 1997, p. 68), meaning, the minimum of fundamental intervention so that through the film the director can merge with the characters in an order that is not made up, but rather seen and reproduced.

Perhaps, it represents just another way of naming what has been defined by Antonio Reis ${ }^{6}$ as Aesthetics of materials. This is immediately apparent in the film Ossos [Bones], when Clotilde's gaze, who wears the cleaning lady's dressing-gown, crosses her gaze with her sister Tina, and is even more evident in Vanda and her light-coloured sweaters. This aesthetics is also shown in the character called Ventura of Juventude em Marcha [Youth on the Move] who, by not changing clothes during the entire movie, wanders from one place to another, from one child to another, or even better, from one plane to another, carrying his simultaneous testimony of shame and pride, as if he is carrying a cross in Via Appia. These observations can be classified under the name of "immobility of clothing", in order to symbolise inertia or lack of will on the part of the protagonists in wanting to change things, an armor that separates them from events.

In particular, it is appropriate to use António Reis's words who also began to understand the totality of a film work, calling Aesthetics of materials to a kind of visual approximation between the filmed object, the subject who films and the cinematographic device itself. Through the trilogies analysed, a pathway could be traced about the emancipation of the clothing from its basic functions to a growing approach to the cinematographic milieu itself, according to Bogatyrëv. By leaving behind the conception of clothing as a mere "coating", it acquires the position of a dramatic element in the communication of the film, along with other stylistic choices.

Often the question arises: what would be the common point between cinema and body clothing, and in particular, if we find any or if they are two parallel worlds that, when they intersect, produce a provisional meaning. Some interesting answers were found in Giuliana Bruno's concept of Sartorial Philosophy (2014) about the integration of fashion in the cinematographic medium. Bruno, in Surface Matters of Aesthetics, Materiality and Media (2014), develops a particular perspective (based on the practice) in which the two worlds are inscribed: in order to make a film, the editing expertise must be put into practice as well the choice of film sequences; also, in the case of fashion, each piece of clothing will result from the combination of various cuts that give it its final appearance. The author nicknames the director of filmmaker-tailor, detecting in the two worlds an indelible bond. Concerning the importance of the body at a filmic level, the author presents a truly

\footnotetext{
${ }^{6}$ Afonso Cautela (in Moutinho \& Lobo, 1997, p. 235) tells in October 1989, after the projection of Rosa de Areia (Sand Rose), in Lisbon, in the debate with the directors, Antonio Reis "alluded at one of the keys of the film: we opted for a Materials Aesthetic. There we play with the strongest and purest materials, from the granitic e basalt stone to the sand (always the sand), to the words (as stones), to the colours, to the textile, to the tile, to the water, to the thatch, to the wine (Porto wine!), to the cultivated sea, to the Earth ocean, all the physical textures that appear.
} 
concerted attitude from the point of view of this work, which aims to elevate the cinematographic clothing to a level of meaning higher than what has traditionally been considered.

It is a process that calls into question what fashion generally represents in the language of cinema, and the restrictive way in which the term is commonly used. It asks us to revise a common understanding that fashion in cinema is simply 'costume design'. In this sense, fashion goes beyond the costume and becomes an altogether different object for the circulation of meaning. (Bruno, 2014, p. 39)

It is not about continuing to understand the fashion element as a separate component within the film, but rather to reformulate its presence as essential to the language of the film, "contributing to the formation of its aesthetic texture" (Bruno, 2014, p. 54) to a degree usually associated with performance, cinematography, montage and set design.

This idea of connecting cinema with other aspects is of particular interest to us in the relation between film and art, between visual practices and aesthetic imagination, and is converted into the urgency of establishing a relation between film studies and other products of Modernity, such as Fashion.

Specifically, we believe that this is an indissoluble nexus already expressed in several essays on costume design in the works of international filmmakers such as Peter Greenaway (Bruzzi, 1997), Wim Wenders, Wong Kar-wai (Bruno, 2002, 2014), Pierpaolo Pasolini Colaiacomo, 2007), Luchino Visconti (Giannone \& Calefato, 2007) Luis Buñuel (Cousins, 2009), and for this reason it needs to be deepened through critical studies, from the national context to reach a broader vision of its potential as a tout-court construction of the cinematographic work. Costume design is also very important to understand the wardrobe of a film, or the whole direction of art, as the creation of socio-historical textures granting to the costume designer, set designer and artistic director some responsibilities regarding the body of the film, its aesthetic and its perception on the screen."

\section{Traduzido por Ondina Pires}

\section{BIBLIOGRAPHIC REFERENCES}

Barthes, R. (1957-1963/2009). I/ sistema della moda. Torino: Einaudi.

Bogatyrëv, P. (1937/1986). Le funzioni del costume popolare nella Slovacchia morava. La ricerca folklorica: contributi allo studio della cultura dele classi popolari, 14, 93-120.

Bourdieu, P. (1998). Meditações pascalianas. Oeiras: Ed. Celta.

Bruno, G. (2002). Atlas of emotion: Journeys in art, architecture, and film. Chicago: University of Chicago Press.

Bruno, G. (2014). Surface, matters of aesthetics, materiality, and media. Chicago: University of Chicago Press.

Bruzzi, S. (1997). Undressing cinema, clothing and identity in the movie. New York: Routledge.

Cabo, R. M. (Ed.) (2009). Cem mil cigarros. Os filmes do Pedro Costa. Lisbon: Orfeu Negro. 
Calefato, P. (2002). Fashion theory. Retrieved from http://www.culturalstudies.it/dizionario/pdf/fashion_ theory.pdf

Calefato, P. (2007). Mass-moda, linguaggio e immaginario del corpo rivestito. Rome: Universale Melteni.

Colaiacomo, P. (2007). L'eleganza faziosa. Pasolini e l'abito maschile. Venezia: Marsilio.

Cook, P. (1996). Fashioning the nation. Costume and identity in British Cinema. London: BFI Publishing.

Costa P., Neyrat C. \& Rector A. (2008). Um melro dourado um ramo de flores uma colher de prata. No Quarto da Vanda. Conversa com Pedro Costa. Lisbon: Midas Filmes e Orfeu Negro.

Cousins, J. (2008). Unstitching the 1950's film à costumes: hidden designers, hidden meanings. Doctoral thesis, University of Exeter, Exeter, United Kingdom. Retrieved from https://ore.exeter.ac.uk/repository/ bitstream/handle/10036/42353/Cousins).pdf?seque

Cucinotta, C. (2015). O vestuário no cinema: percursos de análise em filmes portugueses de etnoficção. Doctoral thesis, New University of Lisbon, Lisbon, Portugal. Retrieved from https://run.unl.pt/ handle/10362/16297

Ferreira, C. O. (2013). O cinema português - aproximações à sua história e indisciplinaridade. São Paulo: Alameda Casa Editorial.

Fidalgo, A. (1999). Da semiótica e seu objecto. Comunicação e Sociedade, 1, 19-40. Retrieved from http:// revistacomsoc.pt/index.php/comsoc/article/view/1436/1366

Giannone, A. \& Calefato, P. (2007). Manuale di comunicazione, sociologia e cultura della moda (volume V, Performance). Rome: Meltemi Editore.

Greimas, A. J. (1985). Del senso 2. Milan: Bompiani.

Levinas, E. (1971). Totalità e infinito. Milan: Jaca Book.

Lurie, A. (2007). Il linguaggio dei vestiti. Rome: Armando Editore.

Marin, L. (1971). Utopiques: jeux d'espaces. Paris: Minuit

Moutinho, A. \& Lobo, M.G. (Eds.) (1997). António Reis e Margarida Cordeiro, a poesia da terra. Faro: Cineclube de Faro.

Mulvey, L. (1978). Piacere visivo e cinema narrativo. Nuova DWF, 8, 26-41.

Onorati, M. G. (2000). Orlando: l'utopia di un corpo in transito. Lectora, 5-6.

Overhoff F. (2013). O cinema português - aproximações à sua história e indisciplinaridade. São Paulo: Alameda casa editorial.

Rascaroli, L. (2009). The personal camera: subjetive cinema and the essay film. London and New York: Wallflower.

Saussure, F., (2009). Corso di linguística generale. Roma-Bari: Laterza

Simmel, G. (1996). La moda. Milan: Oscar Mondadori.

Torres, A. R. (1991-1992). Estética da invisibilidade. A Grande Ilusão, 13-14, 124-125.

Verdone, M. (1986). Scena e costume nel cinema. Rome: Bulzoni editore. 
Veblen, T. (1969). The theory of the leisure class. New York: Modern Lybrary.

Watts, S. (1939). La technique du filme. Paris: Payot.

\section{FILMOGRAHY}

Comissão de iniciativa da Nazareth (Producer), Leitão de Barros, J. (Director). (1927). Nazaré, Praia de Pescadores e Porto de Turismo. Portugal.

Sociedade Universal de Filmes LDA (Producer), Leitão de Barros, J. (Director). (1929). Maria do Mar. Portugal.

Tobis Portuguesa (Producer), Leitão de Barros, J. (Director). (1942). Ala arriba! Portugal.

Instituto Português de Cinema, Ministério da Comunicação Social (Producers), Reis, A. \& Cordeiro, M. (Directors). (1976). Trás-os-Montes. Portugal.

Branco, P. (Producer), Reis, A. \& Cordeiro, M. (Directors). (1982). Ana. Portugal

Secretaria de Estado da Cultura, RTP (Producers), Reis, A. \& Cordeiro, M. (Directors). (1989). Rosa de Areia. Portugal

Branco, P. (Producer), Costa, P. (Director). (1997). Ossos. Portugal

Contracosta Produções, Pandora Film (Producers), Costa, P. (Director). (2000). No Quarto da Vanda. Portugal

Villa-Lobos, F. (Producer), Costa, P. (Director). (2006). Juventude em Marcha. Portugal

\section{BIOGRAPHICAL NOTE}

Caterina Cucinotta has a Phd in Communication Sciences (Film Studies) by New University of Lisbon with a thesis about the costumes in ethnofiction Portuguese cinema, with an FCT fellowship. Actually she's a post doctoral fellowship researcher at CECC (Study Center of Communication and Culture). She has written articles and books chapters, especially about Portuguese Cinema with its relation with Art Direction. She's an AIM (Association for the Moving Image Researchers) member. She has a degree in Art Studies in Palermo with a Master in Cinema and Television Studies in Bologna. She worked as a journalist in Italy and Portugal and also she uses to work in Costumes Department in Cinema and Television.

E-mail: caterina.cucinotta@gmail.com

Rua da Escola Politécnica, 92, $3^{\circ}$ esquerdo, 1250-102, Lisboa, Portugal

* Submitted: 14-10-2016

* Accepted: 23-01-2017 